\title{
SENIORS AS VICTIMS OF DOMESTIC VIOLENCE
}

\author{
Marcela Tittlová \\ Institute of Public Law, Faculty of Law, Pan-European University \\ Bratislava, Slovak Republic \\ marcela.tittlova@paneurouni.com
}

\begin{abstract}
The neglect of seniors is a major problem of the society. In terms of various European documents, maltreatment is qualified as one of the forms of domestic violence. It is undoubtedly one of the latest forms we encounter in domestic violence. The generators of the attacks could be different family members as well as those who are responsible for the care of the seniors. In any case, it is a very negative social phenomenon even in the context of the constant aging of the population and in social and economic context. Seniors are a particularly vulnerable category of people, very similar to children. For this reason, this problem can be considered as an integral and inseparable part of the complex of domestic violence.
\end{abstract}

KEYWORDS: domestic, violence, forms, seniors, criminogenic, factors

JEL CLASSIFICATION: K10, K14, K38

DOI: $10.2478 / \mathrm{IJEK}-2018-0018$

Received: $29^{\text {th }}$ November, 2018

1st Revision: $15^{\text {th }}$ December, 2018

Accepted: $28^{\text {th }}$ December, 2018

Reference: Tittlova, M. (2018). Seniors As Victims Of Domestic Violence. International Journal of Entrepreneurial Knowledge, 6(2), 110-116. doi: 10.2478/IJEK-2018-0018

\section{INTRODUCTION}

As the most essential criterion how the domestic violence can be structuralized, is the criterion of subject, being at the position of the domestic violence victim, as well as the criterion of the nature of the violence itself and its consequences. The nature of domestic violence can vary and we cannot find any estimation or summary in any of accessible literature sources. One of the reasons is that the domestic violence continuously evolves and there are newer, more developed and specific forms of aggressive, violent behaviour, or the violent form itself is significantly dependant on aggressor's subject, his nature and a lot of internal and external factors. Unfortunately, the tools and the procedures used for violent attacks towards the victims are really various, sometimes even absurd (shoe laces, tied by handcuffs, dog leads, etc.). Execution of violent attacks and the tools used for such purposes can vary, depending on particular situation, surrounding or particular interests or preferences of the aggressor (Sopková, 1998).

Typical forms of domestic violence mainly derive from the phenomenological division of domestic violence. This has been based on the spectre of subjects that possibly can or are becoming the domestic violence victims. Based on that, we differentiate either of the following:(Papáček, 2017):

- domestic violence, the victims of which are women,

- domestic violence, executed directly or indirectly on children,

- domestic violence concerning men,

- domestic violence, the victims of which are older people (seniors),

- domestic violence, concerning mentally or physically challenged people.

From frequency point of view, we can agree with opinion that the most frequent violence is executed on women (Polák, Tittlová, 2017). Woman represents a typical victim of domestic 
violence and due to this the domestic violence is incorrectly limited mainly to this group. From the same point of view, the second numerous group are the children victims. What is interesting is the fact that not real numbers of either women or children victims are known but it is assumed that the number is much higher than those officially recorded (Knápková, Tóthová, 2010). The problem is that the violence on women and domestic violence in general is highly latent. It is very similar in case of violence commited on children, the revealing of which is more and more assisted by social institutions of the states. Highly latent form of domestic violence is also the one commited on men. Nevertheless, we also face the problem of seniors neglected, what also can be considered to be the form of domestic violence within its global society and the most modern understanding.

\section{SENIORS AS THE CATEGORY OF DOMESTIC VIOLENCE VICTIMS}

The latest category of victims of domestic violence is the category of seniors. The term senior has been, under our conditions, related to the pension age but also younger people can be included. The violence itself is done mostly by their children or grandchildren. Therefore, it is more convenient to describe the group of older people than the ones who are having children or grandchildren, offsprings causing the violent behaviour. Most of the aged people would never admit such violent behaviour to be commited on them. There is only about between $3-5 \%$ of explored cases of seniors admitting the domestic violence commited on them (Holcr, 2017). The real situation might be radically different. The behaviour of their children is, according to them, due to work stress, new, modern age or different interpersonal problems. Finally, older people are very grateful for every kind of attention from their children, and the violent behaviour sometimes and somehow compensates that. There is a tendency to lighten the violent attacks and afterwards they can soon forgive their children. At the same time, many of such attacks are not motivated only by their problem situation with seniors and new situation for the children (when they have to take care of their parents, being som difficult due to work and other duties they have), but also there is the financial and property motivation very often (Polák, Tittlová, 2017).

In cases of seniors or children, as the victims of domestic violence, we can often come across the term of being neglected. Such a form is a part of supranational documents and its content creates the overall neglection of mental, physical and moral care. The neglected people are usually unwashed, wearing dirty clothes, undernourished, hungry and weak, unwell, due to lack of vitamins and food, laconic due to physical torture or they refuse communication, often mentally behind, or challenged in general. It integrates physical and mental attacks, aimed to overall neglection of senior person. Seniors can find themselves in such positions mainly due to health problem reasons. It is similar as with children, failure in nourishing, hygiene, social contact, moral or mental development. Such a form can be typical for health challenged people, basically dependant on partial or complex help from other people. And it is them who intentionally neglect such duties (Papáček, 2017).

\section{THE TERM DOMESTIC VIOLENCE ON SENIORS AND ITS FORMS}

What we understand under the term of domestic violence of older people is the violence commited on parents by their children or on grandparents by their grandchildren. Generally, the old age means the age overreaching 60 years, though such criterion is very disputative. It is related to continuously shifting pension age and involves the real age of people when they retire. There is a myth that seniors are often inert, weak, dependant on the help of the others. Despite the fact that there are such groups, not all the cases must be like this. There is a large group of vital, mobile and self-sufficient seniors, in some cases even at work. Thus they are not a burden for the society. At the same time, any of such seniors, either vital or dependant, can become the victim of domestic violence. Such phenomenon is highly specific for this category, compared to other crime forms. The senior victims can be divided according to what is their life-circumstances situation and based on this, the proper approach and tools to help such 
victims can be chosen and vary. The following groups of senior domestic violence victims can be recognized (Tittlová, 2017):

- seniors physically vital and living active life,

- seniors physically vital, but lonely (mostly widowed) or those ones having bad financial situation,

- seniors immobile, having problems to move or possibly somehow disabled, handicapped,

- seniors mentally unstable or challenged.

Either of the above mentioned groups, while taking the older aged people into consideration, can become the victim of domestic violence. We can talk about domestic violence involving seniors only in cases when children or grandchildren are the aggressors. Based on the violence causer, also other types of domestic violence can be taken into consideration. It is often the term of neglect used instead of domestic violence. Most of supranational documents, mainly the EU documents dealing with this issue, highlight it in the previous way. Neglect, in this case, does not involve only passive, but also active forms of domestic violence. Basically, the nature of the attacks towards the seniors is physical, mental, intimate, economic or social. It is similar as in case of children, being negleted, that is providing insufficient care, hygiene, food, rest or emotions. It is, more or less, about all the attacks involving physical or mental harm or damage of the senior person. The most frequent are the mental attacks aimed as highlighting inutility or inability of senior person, taking his age and general health into consideration. The physical attacks also belong to frequent ones and as the person grows older and is getting weaker, all the physical attacks are clearly more visible and seen. There are the marks of physical attacks, so unfavourable from the aggressor's point of view. Recently, the media keep us informed that intimate violence on seniors has been more and more bewildering. Frequently, it is about economic, property attacks, including witholding of pensions, leaving only a small portion of it at senior's disposal, etc. It is dangerous how neglecting the seniors, inevitably dependant on the help of the others, can be. The nature of the attacks can vary quite a lot. It is estimated that the most frequent aggressors are children or grandchildren of seniors $(60 \%)$. Besides, there is the group of nursing and retirement home personnel, being obliged to take care of seniors. Taking the helplessness and powerlessness into acount, seniors are quite easily abused. The percentage of such problems facing seniors is increasing. Čírtková (2004) mentions that the risk of senior neglect is being on increase year by year. Growing older is generally characterized by physical power and sturdiness decrease, though many older seniors remain physically active. The body shows the features of being worn, certain ilnesses appear. Frequent are the mental problems, like - forgetting, senility, gradual dementia, etc. All these signs are naturally connected to senior age but despite that it is difficult to react to them. Children usually cannot bear the fact that this also involves their parents. They treat them as it used to be years ago but that does not reflect the reality. The emerged situations require not only patience but also financial cover and mainly some time. In many cases, the variety of situations, inability to manage them or to help, represent a strong stress factor, leading to tension. Its final phase is to release the tension by violent attacks, bad or insufficient treatment of seniors.

\section{SYNDROM OF BAD TREATMENT OF SENIORS AND ITS IDENTIFICATION}

Syndrom of bad treatment of seniors or neglecting them (EAN syndrom) was described for the first time by the European Council. Its content is created by all the available and known forms of violence, including the property exploitation and forgetting the basic existential needs of seniors. All of these attacks are primary aimed to harm or hurt. Aggressors' deeds lead to cause suffer, not destruction (Medelská, 2017). Unfortunately, due to physical attacks, the death of seniors is happening. An important role is played by a fact that it is about being more vulnerable, the attacks of such extent would not mean a danger for a person in productive age. The above mentioned aspect, describing the neglect of seniors, also specified the typical forms of such violent behaviour (Tittlová, 2017). They involve the following: 
- direct physical ill usage (different forms of beating, using different tools),

- indirect physical ill usage (purposeful delay or skipping of the medications),

- intimate violence (intimate touching, stalking while having shower or changing clothes, different types of sexual activities),

- emotional torturing (most often verbal offence, ignoration, hiding the feelings, threatening, humiliating, mockery, highlighting the inability, uselessness, telling off the collective, highlighting the burden they represent, etc.),

- misusage of seniors from material or financial point of view (take the pension rent, stealing money, valuables or other things from household, forcing to donate or gift the property emphasizing the common care),

- neglecting the help, seniors inevitably need for their life (caring about hygiene routines, helping with hygiene, not providing food, drinking, proper clothes, cleanness, in case of immobile people it can cause sore bed, sore spots, etc.),

- forcing the seniors to leave the dwellings where they spent a part of their life,

- forcing the seniors to leave into retrieves with special care despite the fact that senior does not suffer any health problems to be there, etc.

Violence identification on seniors is not an easy subject at all. Seniors often try to hide such violence by different ways. They are shy people, often dependent on the help of others, they appreciate the good will and being afraid of the aggressor, they often do not report the domestic violence. They are afraid of having and making the situation even worse and at the same time they wish for the attention from their children or grandchildren. The violence they survived is a difficult topic to deal with for them, or they prefer not to talk about at all. They show signs of uncertainty, being unstable or afraid of in communication, and these can be revealing a lot about problems. Discovering the violence on seniors is made even worse by the social situation in society is not very helpful towards this group. Financial security is relatively low, some of the treatments connected to the domestic violence have effect also on the current questions concerning pensioners.

Caring about seniors, with different activity level in older age represent certain burden. Currently, it is very difficult to synchronize own work and family life with taking care of parents. The bigger the health problems are, the more difficult and demanding is taking care of them. It requires many limitations from the families, often not only as to time but also material or financial. Similar negative impact as neglect of seniors has also the insufficient or unmanaged care. Subjects providing the care from among family members are mostly not qualified or educated properly to handle such difficult tasks. Overloading or high pressure belongs to most common risk factors in case of aggressors.

\section{REASONS TO NEGLECT THE SENIORS (THE MOST COMMON ONES)}

Specific category of victims of domestic violence are seniors, either from the above mentioned forms of domestic violence or from the reasons of such behaviour towards seniors. Seniors often have tendency to disregard the domestic violence, they suffer and bear the frequent repeated attacks. Some of them are simply unable to solve such problems due to their physical and mental condition. Many of them do not talk or mention that despite the fact they should and could. They are grateful for each kind of attention, any interest from aggressor's side or they consider themselves to be a burden so they decide to accept the violence. Sometimes they are afraid of being ashamed and they have the feeling of failure in upbringing the aggressor, often the only close relative they have so the relationship is not interrupted and the domestic violence is not being solved either. The reasons of domestic violence on seniors are different, caused by - stress, financial or material ones. Risk factors for seniors are the following ones, mainly: (Polák, Tittlová, 2018):

- old age,

- physical weakness, 
- typical illnesses for older age, more serious illnesses, connected to worn body condition,

- mental disorders, illnesses,

- the need to take care of senior, that he is wholly dependent,

- financially demanding treatment,

- property and financial background.

Taking care of seniors, similar as about physically challenged people, is not easy at all, it often requires certain special knowledge, qualification, or frequent visits to doctors. The aggressor usually has his own family, his own life he has to exist in, so taking care about senior is becoming very demanding from every point of view. Senior, from aggressor's point of view, is becomming a tiring burden and he cannot devote himself to what he would like to (his work, family, interests), and this leads to helplessness, feeling tired, often anger or exhaustion. In some cases it is the helplessness in aggressor's case when he cannot provide the care in proper way, senior is unconsciously neglected and thus he is harmed. All these feelings - cause frustration, a significant risk factor. It is often the base where the domestic vilence starts to occur. Generally, these are physical attacks, mental torture or neglect of seniors. Similar situation is also in case of disabled people. What surprises is that the victims of violence are seniors from property or financial reasons. The aggressor is a grandson, getting this way the part or the whole of the pension income of senior. Aggressors often are interested in other property of senior (different immovables or valuable movables). Children's violent behaviour can be motivated by inheriting the property rights or forcing the senior to leave the place of dwelling (such as shared house or flat) and leave to retirement home for seniors.

Besides the family care, recently the problem appears also in specialized care centres in homes or nursing homes. In cases of physically or mentally challenged seniors this seems the only worth place to live. Seniors are offered special medical care. Though these institutions, often private ones or financially donated by the families of seniors, are not doing the caring job properly. Most of such institutions have a bad reputation, in many cases even unreasonable death cases, showing the bad conditions or insufficiencies in such places. Despite these facts, complex surveys on treatments are absent. The activities are being monitored by health care employees from insurance companies but neglection is often covered and often hidden by announcing the controlling activities in advance.

It also involves the subjects, according to ex lege or contracting conditions, obliged to provide the senior care, who commit the violence on older people and neglect them. This also can be considered to be one of the forms of domestic violence. Within the care and providing the needs of seniors there were discovered numerous failures (not enough drinking water, food, vitamins, excessive amount of sedatives, limitations in individual freedom, disturbing the privacy, unreasonable monitoring the senior, etc.). Instead of proper care, the currently operating institutions (many of them) can be characterized with adjectives as irresponsible, not qualified, not interested or careless.

Solving the senior neglect problems has more structural aspects and it is not that simple at all. Many of seniors cannot express their opinion, neither to protect themselves, nor to report the violence commited on them. Even if they have such possibility, they do not know about it. A matter of a fact is that they grew up in completely different social, political, legal environment where the function of the family and its hierarchy used to be perceived in a different way as it is today. Seniors, in relation to nurses or pension home management, do not know their rights. Disturbing their privacy or unreasonable monitoring is often perceived as common operation run of the treatment centre or institution. As to relation to the surrounding, there is the feeling of helplessness that they are placed in such institution. When the aggressors are their own children, their behaviour is understood as a failure in upbringing and they do not want to present this publicly. Finally, every attention, even the negative one, means that they are grateful for that to their relatives. As to the status of seniors, neither their financial, nor the social perceiving help. Members of the society often underestimate seniors, according to their opinion they are on the edge of society, mostly as a burden instead of help. It is important to 
mention that despite the financial point of view, the seniors are full-valued members of the society. Therefore, the state should guarantee the rights and provide them worthy period of growing old and react by proper legal and non-legal means to each form of domestic violence involving seniors.

Domestic violence on seniors, taking the above mentioned reasons into consideration, has a typical feature that it is not that simple for the victims to set free, despite that it might seem easy to do so. At the beginning they are gathering strength to recover then later they are trying to justify the deeds. The aggressor's appologies that the attacks will not be repeated persuade mostly the victims to believe in that. Seniors, in this phase, no matter what the behaviour of the aggressor is, are not able to protect themselves against the forthcoming attacks. The violent attacks are accompanied by appologies from aggressor, with different reasons (mostly due to external factors as stress, tension, etc.). The victims are getting into helpless situation. Taking all the relations with aggressor into consideration, only a small portion can break away. The longer the victims remain in relation with aggressor and the more often the attacks are happening, the lower is the probability to find solution for the victims. Many of the victims are ashamed and they think it was their failure and unability, and there are still many women who believe that they must bear the violence towards their personality. Not many children can oppose the authority of their parents and mention the behaviour of them at school or among friends. Seniors are ashamed for the behaviour of their children, they are happy for every small attention paid towards them, no matter that small acts of kindness are alternating with different types of attacks (physical, mental, terrorizing and humiliation, etc.). Men can only rarely bear the situation that they are in the position od the victims of domestic violence. They would never accept the idea of violent behaviour on them.

\section{CONCLUSION}

The problem of domestic violence is the persisting one. It is important to perceive the phenomenon as the complex one from different forms of violent behaviour, from the subject point of view, when we can talk about the domestic violence victims. Later, but after all, also the older people - seniors, are ranked among the victims of domestic violence. This phenomenon is quite a new one. In every case, it is necessary to pay attention to different forms of senior neglect. It is strongly specific phenomenon, taking the age of victims into consideration, at the same time it belongs to highly latent one, either due to shame or the helplessness of seniors. Therefore, the phenomenon must be examined, prepare the social and legal tools to control and sanction it.

\section{Acknowledgement}

The contribution was elaborated as a part of the research project APVV 'Možnosti kriminologického a trestnoprávneho riešenia domáceho násilia' [transl.: Possibilities of Criminological and Criminal Law Solutions of Domestic Violence] No. APVV-15-0644. Head of the project - doc. JUDr. Peter Polák, $\mathrm{PhD}$.

\section{REFERENCES}

Holcr, K. (2017). Obete násilnej kriminality medzi príbuznými v policajných štatistikách. In Polák, P., Tittlová, M. (2017). Kriminologické možnosti riešenia domáceho násilia. Bratislava: Wolters Kluwer, 2017, 514-532.

Knápková, D., Tóthová, M. (2010). Deti ako obete domáceho násilia. In Zborník príspevkov z. medæinárodnej vedeckej konferencie DNY PRÁVA 2010, Brno, Právnická Fakulta MU v Brne, 2010, $1-18$. 
Medelská, Z. (2017). Netrestnoprávne inštitúty riešenia domáceho násilia. In Polák, P., Tittlová, M. (2017). Kriminologické možnosti riešenia domáceho násilia. Bratislava: Wolters Kluwer, 2017, $245-262$.

Papáček, P. (2017). Základné formy domáceho násilia. In Polák, P., Tittlová, M. (2017). Kriminologické možnosti riešenia domáceho násilia. Bratislava: Wolters Kluwer, 2017, 465-476.

Polák, P., Tittlová. M. (2018). Kriminologické aspekty domáceho násilia. Bratislava: Wolters Kluwer, 2018, 330

Polák, P., Tittlová, M. (2017). Kriminologické možnosti riešenia domáceho násilia. Bratislava: Wolters Kluwer, 2017, 565.

Tittlová, M. (2017). Pojem a znaky domáceho násilia. In Polák, P., Tittlová, M. (2017). Kriminologické možnosti riešenia domáceho násilia. Bratislava: Wolters Kluwer, 2017, 18-29. 